\title{
INOVASI LEKSIKAL BAHASA WOTU
}

\author{
Wotu Language Lectical Innovation
}

\author{
Suparman \\ Universitas Cokroaminoto Palopo \\ suparman@uncp.ac.id
}

Naskah Diterima Tanggal 7 Februari 2019—Direvisi Akhir Tanggal 4 November 2019—Disetujui Tanggal 19 Desember 2019 DOI : $10.26499 /$ rnh.v8i2.1282

\begin{abstract}
Abstrak
Tujuan penelitian ini adalah untuk mendeskripsikan inovasi leksikal bahasa Wotu, yaitu mendeskripsikan daftar kata yang mengalami inovasi dengan menggunakan metode kualitatif atau pendekatan secara langsung terhadap fenomena kebahasaan yang terjadi di Kecamatan Wotu, Kabupaten Luwu Timur melalui proses observasi, wawancara, teknik catat, dan reduksi data. Data yang diperoleh mencakup inovasi fonetis yang terdiri atas penggantian bunyi vokal dan konsonan, penambahan bunyi vokal dan konsonan, penghilangan bunyi vokal dan konsonan serta gugus konsonan pada posisi kanan, inovasi makna, inovasi morfologi yang terdiri atas prefiks, sufiks, afiks dan reduplikasi, serta inovasi leksikal yang terdiri atas inovasi leksikal, inovasi leksikal parsial, dan inovasi leksikal penuh.
\end{abstract}

Kata-kata Kunci: inovasi, leksikal, dialektologi, Wotu

\begin{abstract}
The purpose of this study is to describe the lexical innovation of Wotu dialect, namely describing a list of words that experience innovation by using qualitative methods or a direct approach to linguistic phenomena that occur in Wotu District, East Luwu District through an observation, interview, note taking technique and data reduction. The data obtained includes phonetic innovations consisting of substitution of vowel and consonant sounds, addition of vowel and consonant sounds, vowel sounds and consonants and consonant groups in the right position, meaning innovation, morphological innovations consisting of prefixes, suffixes, affixes and reduplications and lexical innovation consisting of lexical innovation, partial lexical innovation and full lexical innovation.
\end{abstract}

Keywords: lexical innovation, dialectology, Wotu

How to Cite: Suparman. (2019). Inovasi Leksikal Bahasa Wotu. Ranah: Jurnal Kajian Bahasa, 8 (2), 219-236. doi: https://doi.org/10.26499/rnh.v8i2.1282

\section{PENDAHULUAN}

Masyarakat Indonesia yang secara geografis tersebar luas dan bermukim di seantero Nusantara memiliki keberagaman suku bangsa yang multilingual. Persebaran pemukiman penduduk di tiap wilayah akan menciptakan kelompok 
Inovasi Leksikal...

atau komunitas dengan bahasa daerah yang berbeda-beda, Masyarakat Indonesia yang secara geografis tersebar luas dan bermukim di seantero nusantara memiliki keberagaman suku bangsa yang multilingual. Persebaran pemukiman penduduk di tiap wilayah akan menciptakan kelompok atau komunitas dengan bahasa daerah yang berbeda-beda (Syahrir, 2018, hlm. 196).

Indonesia kini memiliki beberapa keadaan kebahasaan yang juga perlu diperhatikan. Pertama, adanya bahasa nasional yang sekaligus menjadi bahasa negara; kedua, adanya ratusan bahasa daerah yang tersebar di berbagai pelosok Indonesia; dan ketiga, adanya sejumlah bahasa asing, yang digunakan atau diajarkan dalam pendidikan formal (Chaer dan Agustina, 2010, hlm.225). Ketiga keadaan kebahasaan ini secara sendiri-sendiri mempunyai masalah, dan secara bersama-sama juga menimbulkan masalah yang cukup kompleks, yang perlu diselesaikan sehingga bahasa di Indonesia, khususnya bahasa daerah, tidak terancam punah.

Bahasa memiliki keunikan dan kreativitas tersendiri di setiap daerah, sehingga terbentuk inovasi. Perbedaan atau variasi dan juga kekreatifan bahasa dalam setiap daerah memicu, terciptanya inovasi. Menurut Kridalaksana (1993), inovasi merupakan perubahan bunyi, bentuk, atau makna yang mengakibatkan terciptanya bahasa baru. Pei (1996) juga berpendapat bahwa Inovasi adalah perubahan bunyi, bentuk kata, atau arti yang bermula dari lokasi geografis tertentu, kemudian menyebar ke wilayah sekitarnya, sedangkan leksikal merupakan perbendaharaan kata yang dimiliki oleh Bahasa.

Bahasa muncul dalam berbagai variasi. Variasi bahasa itu dikelompokan dangan cara tertentu. Poedjosoedarmo (dalam Suriono, 2016, hlm. 2) mengemukakan adanya tujuh faktor penentu penjenisan variasi bahasa: pribadi penutur, asal kelas sosial, suasana atau tempat penutur, relasi O1-O2, tujuan tutur, topik atau ranah tutur, dan perasaan penutur. Ketujuh faktor penjenisan variasi bahasa itu menghasilkan tujuh variasi bahasa: idiolek, dialek, ragam, undak usuk, register, jargon, dan genre.

Inovasi merupakan hal-hal baru atau perubahan. Menurut Wahya (dalam Kurniawati, 2005, hlm. 52-53), inovasi adalah perubahan bunyi, bentuk kata, atau arti, yang bermula dari lokasi geografis tertentu dan menyebar ke wilayah sekitarnya atau bermula dari perseorangan dan menyebar melalui peniruan kepada anggota masyarakat penutur lain. Sementara itu, menurut Mahsun (dalam Kurniawati 1995, hlm. 84-86), 
inovasi bahasa digunakan untuk menyebut unsur-unsur bahasa yang mengalami perubahan.

Menurut Mahsun (dalam Toha, 2016, hlm. 88) upaya memelihara bahasa daerah perlu dilakukan karena sikap penutur bahasa daerah yang kurang positif terhadap bahasa daerahnya. Hal ini disebabkan penutur bahasa daerah (sebagian besar bahasa daerah yang ada di Indonesia) yang relatif kecil jumlahnya. Oleh karena itu, mereka memandang dirinya sebagai kelompok minoritas yang kurang prestise dan pemakaian bahasa Indonesia yang semakin dominan dalam berbagai aspek kehidupan. Upaya pengembangan dilakukan melalui penelitian bahasa-bahasa daerah, seperti pada aspek kebahasaannya

Di Indonesia terdapat berbagai macam suku bangsa dan daerah. Hampir setiap daerah memiliki beragam bahasa. Keragaman atau variasi bahasa ini tentu saja terjadi karena ada penyebabnya dan berkaitan dengan perubahan bahasa. Perubahan bahasa ini dapat dilihat pada unsur tertentu yang terdapat pada variasi sosial dan variasi geografis. Di samping itu, ragam dialek yang terjadi antardaerah juga berpengaruh terhadap ragam bahasa.

Di daerah Luwu terdapat banyak bahasa yang digunakan oleh masyarkat Luwu. Salah satunya adalah bahasa Wotu, yang penuturnya tergolong minoritas. Bahasa Wotu merupakan salah satu contoh bahasa yang terancam punah di Sulawesi Selatan. Masyarakat etnis Wotu yang tersebar di dua desa, yaitu Desa Lampenai dan Desa Bawalipu. Jumlah penutur bahasa Wotu yang aktif makin sedikit seiring dengan kematian generasi tua dan makin jarangnya generasi usia sekolah yang menjadi penutur aktif bahasa Wotu. Generasi muda Wotu cenderung menggunakan bahasa Indonesia dan bahasa daerah lain, seperti bahasa Bugis. Hal ini terjadi karena, Kecamatan Wotu dikelilingi beberapa penutur bahasa lain, seperti penutur bahasa Tomoni atau penutur bahasa Pamona dan penutur bahasa Bugis.

Penelitian ini menjelaskan inovasi leksikal bahasa Wotu di daerah Luwu Timur, Sulawesi Selatan. Variasi atau inovasi yang terdapat dalam bahasa Wotu meliputi inovasi fonetis, inovasi makna, inovasi morfologi, dan inovasi leksikal.

Penulis tertarik meneliti bahasa Wotu karena menurut penulis, bahasa Wotu unik. Keunikan terdapat pada inovasi fonetis, inovasi makna, inovasi morfologi, dan inovasi leksikal. Hal tersebut menggambarkan proses terjadinya inovasi leksikal dalam bahasa 
Inovasi Leksikal...

Wotu di Kabupaten Luwu Timur, Sulawesi Selatan. Berdasarkan gagasan tersebut, peniliti perlu melakukan penelitian mengenai inovasi yang terjadi pada bahasa Wotu.

Berdasarkan latar belakang tersebut, penulis merumuskan masalah dalam penelitian ini, yaitu bagaimanakah inovasi leksikal pada bahasa Wotu? Penelitian ini diharapkan dapat memberikan sumbangsih kepada berbagai pihak, khususnya di bidang linguistik, serta masyarakat Wotu sebagai pemilik bahasa tersebut, khususnya generasi muda yang sudah mulai meninggalkan bahasa Wotu sebagai bahasa ibu. Penulis berharap penelitian ini dapat dijadikan sebagai sarana pengenalan bahasa daerah kepada peserta didik karena bahasa di dunia bersifat unik dan dinamis.

\section{LANDASAN TEORI}

Sudika (2010) dalam penelitiannya "Inovasi Leksikal Bahasa Bali di Lombok menunjukkan bahwa inovasi leksikal bahasa Bali di Lombok ditemukan dalam dua bentuk, yaitu inovasi internal dan inovasi eksternal. Inovasi internal dapat berupa bentuk perubahan bunyi, penambahan bunyi, dan penghilangan bunyi. Adapun inovasi eksternalnya adalah, bahasa Bali sangat kuat dipengaruhi oleh bahasa Sasak. Persebaran unsur pungutan dari bahasa Sasak di dalam kedua dialek itu terjadi secara tidak merata. Ketidakmerataan itu telah memperlihatkan bahwa dalam dialek yang terpencil memperlihatkan pengaruh unsur pungutan bahasa Sasak. Frekuensinya lebih tinggi dibandingkan dengan keterpengaruhannya pada daerah yang tidak terpencil. Inovasi internal yang dialami daerah dialek Pl yang merupakan daerah pencilan memperlihatkan inovasi internalnya rendah.

Mustafa (2015) dalam penelitiannya Kajian Dialek Geografi pada Inovasi Leksikal Penuh Bahasa Melayu Riau Dialek Kampar di Kecamatan Kampar Timur memaparkan bahwa penelitian Mustafa dapat dilihat berdasarkan pewujudan inovasi. Inovasi leksikal penuh termuat 41 glos dengan 131 varian pada titik pengamatan 2, yaitu di Kecamatan Kampar Timur Desa Teratak. Medan makna yang banyak menampilkan leksikal penuh adalah kekerabatan sebanyak 5 leksikal penuh dengan 14 varian inovatif bahasa Melayu Riau di Kecamatan Kampar Timur, Kabupaten Kampar.

Pembaruan atau inovasi adalah perubahan bunyi, bentuk, atau makna yang mengakibatkan terciptanya kata baru (Kridalaksana, 1993, hlm. 84). Sehubugan dengan itu, pandangan (Wahya, 2006, hlm. 52) tentang inovasi dapat dilihat dari dua sisi, yakni 
proses dan hasil. Sebagai proses, inovasi adalah terciptanya bentuk dan/atau makna baru akibat adanya perubahan bentuk atau makna asalnya. Sebagai hasil, inovasi adalah bentuk dan atau makna baru yang muncul di wilayah pakai isolek yang bersangkutan. Inovasi bahasa dapat terjadi, baik dari dalam maupun dari luar. Inovasi dari dalam berkaitan dengan pembaruan sistem bahasa akibat adanya potensi dalam bahasa itu sendiri. Inovasi dari luar berkaitan dengan pembaruan sistem bahasa akibat pengaruh dari bahasa lain.

Inovasi adalah unsur warisan bahasa asal yang telah mengalami perubahan pada masa sekarang, (Anderson dalam Adihti, 2016, hlm. 51). Apabila terjadi perubahan pada kelompok bahasa turunan dan tidak terjadi pada kelompok bahasa lain dalam perkembangannya, perubahan itu disebut inovasi bersama eksklusif.

Inovasi yang terjadi bisa bersifat internal atau eksternal. Inovasi internal merupakan pembaruan yang terjadi dalam kelompok atau subkelompok bahasa tertentu (Cahyono, 1995, hlm. 358). Inovasi internal adalah perubahan yang terjadi karena adanya kontak dengan bahasa asing atau bahasa selain bahasa itu sendiri dengan adanya elemen-elemen serapan di luar kelompok bahasa itu.

Menurut Pei (dalam Mustafa dkk., 2015, hlm. 549), inovasi adalah perubahan bunyi, bentuk kata, atau arti, yang bermula dari lokasi geografis tertentu dan menyebar ke wilayah sekitarnya atau bermula dari perseorangan dan menyebar melalui peniruan kepada anggota lain masyarakat tutur. Mahsun (dalam Mustafa dkk., 2015, hlm. 549) berpendapat bahwa inovasi digunakan untuk menyebut unsur-unsur bahasa yang telah mengalami perubahan.

Pengaruh satu bahasa terhadap bahasa lain terjadi berupa leksikon yang mengalami pembaruan atau inovasi yang, menurut Kridalaksana (dalam Junawaroh, 2010, hlm. 105) adalah perubahan bunyi, bentuk, atau makna yang mengakibatkan terciptanya kata baru. Inovasi bahasa dapat terjadi dari dalam dan dari luar. Inovasi dari dalam berkaitan dengan pembaruan sistem bahasa akibat adanya potensi dalam bahasa itu sendiri. Inovasi dari luar berkaitan dengan pembaruan sistem bahasa akibat pengaruh dari bahasa lain. Inovasi dari luar dilakukan dengan cara menyerap unsur isolek lain sehingga pembaruan jenis ini sering dianggap penyerapan unsur isolek lain, (Mahsun dalam Junawaroh, 2010, hlm. 105). Inovasi dari dalam dan dari luar meliputi pembaruan leksikal dan gramatikal, (Wahya dalam Junawaroh, 2010, hlm. 105). Perwujudan 
Inovasi Leksikal...

Inovasi menurut Wahya meliputi inovasi bentuk dan inovasi makna. Inovasi bentuk dapat berwujud inovasi bentuk leksikal, inovasi fonetis, inovasi morfologis, dan inovasi semantis. Inovasi makna meliputi inovasi makna leksikal yang berupa penyempitan makna, perluasan makna, atau berupa perubahan kualitas makna.

Mahsun (dalam Mustafa dkk., 2015, hlm. 549) lebih lanjut berpendapat bahwa unsur pembaruan dalam dialektologi perlu dibedakan dengan unsur pembaruan dalam linguistik historis komparatif. Dalam dialektologi, pembaruan (inovasi) mengandung pengertian bahwa unsur tersebut berupa unsur yang sama sekali baru, bukan unsur pewarisan dari suatu bahasa purba yang telah mengalami adaptasi fonologi sesuai dengan kaidah perubahan bunyi yang berlaku. Unsur pembaruan dalam dialektologi memiliki ciri berikut.

1) Unsur itu merupakan unsur yang sama sekali baru, tidak memiliki pasangan kognat dalam bahasa, dialek, subdialek, atau daerah pengamatan lain.

2) Unsur itu memiliki kesamaan dalam bahasa, dialek, subdialek, dan daerah pengamatan lain, mungkin unsur itu warisan dari suatu bahasa purba yang sama atau hasil inovasi internal, tetapi keberadaan unsur itu (sebagai inovasi) tidak sesuai dengan sistem isolek dari dialek, subdialek, daerah pengamatan (yang menerima unsur itu), dan distribusi unsur terbatas dibandingkan dengan distribusi unsur tersebut dalam bahasa, dialek, dan subndialek yang diduga sebagai sumbernya.

\section{METODE PENELITIAN}

Metode deskriptif dapat diartikan sebagai prosedur pemecahan masalah yang diselidiki dengan menggambarkan atau melukiskan keadaan subjek atau objek penelitian pada saat sekarang berdasarkan fakta-fakta yang tampak atau sebagaimana adanya. Pendekatan kualitatif berarti berusaha memahami fenomena sosial kebahasaan yang tengah diteliti. Istilah memahami diartikan sebagai usaha mencari makna suatu fenomena yang diteliti sesuai dengan pemahaman para subjeknya, fenomena dari segi kebahasaan yang dimaksud adalah inovasi leksikalnya. Penelitian kualitatif sangat terlibat dalam interaksi dengan realitas yang ditelitinya dan, mendeskripsikan fenomena yang menjadi fakta dan sarana penelitian secara alamiah. Alamiah berarti fenomena 
yang menjadi sasaran penelitian, dideskripsikan sebagaimana adanya tanpa disertai perlakuan, pengukuran, dan perhitungan statistik.

Data yang digunakan dalam penelitian ini adalah tuturan bahasa Wotu, sedangkan Sumber datanya adalah penutur bahasa Wotu, yaitu masyarakat Kecamatan Wotu.

Dalam penelitian ini digunakan metode simak. Metode ini memiliki teknik dasar yang berwujud teknik sadap. Teknik sadap dikatakan sebagai teknik dasar dalam metode simak karena pada hakikatnya penyimakan diwujudkan dengan penyadapan ataun dalam upaya mendapatkan data, peneliti menyadap penggunaan bahasa seseorang atau beberapa orang yang menjadi informan. Dalam praktik selanjutnya, teknik sadap dilakukan dengan teknik lanjutan yang berupa teknik simak bebas libat cakap, catat, dan teknik rekam.

Analisis data yaitu memakai metode reduksi data, peneliti memilih hal-hal pokok yang sesuai dengan fokus penelitian. Reduksi data merupakan suatu bentuk analisis yang menggolongkan, mengarahkan, membuang yang tidak perlu, serta mengorganisasikan data-data yang telah direduksi, memberikan gambaran yang lebih tajam tentang hasil pengamatan, dan mempermudah peneliti menemukannya jika sewaktu-waktu diperlukan.

\section{PEMBAHASAN}

\section{Inovasi Fonetis}

1) Penggantian vokal

Penggantian vokal dalam data inovasi fonetis mengacu pada berubahnya bunyi vokal kata dasar ke bunyi vokal lain yang menghasilkan bunyi baru. Kemungkinan besar hal ini terjadi diakibatkan banyaknya bahasa berkerabat yang digunakan oleh masyarakat sekitaran Kecamatan Wotu. Dalam penelitian ini ditemukan 31 glos yang mengalami penggantian vokal, terdiri atas bunyi vokal /a/, /i/, /u/, /e/ dan /o/. Berikut ini adalah data yang mengalami penggantian vokal.

Tabel 1. Data Penggantian Vokal Bahasa Wotu

\begin{tabular}{cccc}
\hline No. & Glos & Dialek Wotu & $\begin{array}{c}\text { Penggantian Vokal } \\
\text { Bahasa Wotu }\end{array}$ \\
\hline 1. & Ikat & Babba & Bebbe \\
2. & Robek & Bengka & Bangka \\
3. & Bedak & Badda & Bedda \\
4. & Samping & Banre & Benre \\
5. & Kunyah yang berbunyi & Garappu & Gareppu
\end{tabular}


Inovasi Leksikal...

$\begin{array}{lccc}6 . & \text { Bentak } & \text { Garra } & \text { Gerra } \\ 7 . & \text { Diperjelas } & \text { Ipenassai } & \text { Ipanessai } \\ 8 . & \text { Melakang } & \text { Monri } & \text { Munri } \\ 9 . & \text { Cakar } & \text { Karabbe } & \text { Karebbe } \\ 10 . & \text { Lembab } & \text { Makammu } & \text { Makemmu } \\ 11 . & \text { Kenangis } & \text { Karra } & \text { Kerra } \\ 12 . & \text { Muntah } & \text { Tollua } & \text { Tallua } \\ 13 . & \text { Lipat } & \text { Luppi } & \text { Leppi } \\ 14 . & \text { Lumpur } & \text { Lombu } & \text { Labbu } \\ 15 . & \text { Mati atau meninggal } & \text { Lappu } & \text { Leppu }\end{array}$

Berdasarkan data tersebut, penggantian vokal inovasi fonetis dapat dijelaskan sesuai dengan urutan katanya, yaitu babba 'ikat' berubah menjadi 'bebbe' dengan perubahan bunyi vokal /a/ menjadi /e/; bengka 'robek' atau 'sobek' berubah menjadi bangka dengan perubahan bunyi vokal /e/ menjadi /a/; badda 'bedak' berubah menjadi bedda dengan perubahan bunyi vokal /a/ menjadi /e/; banre 'samping' berubah menjadi benre dengan perubahan bunyi vokal/a/ menjadi /e/; garappu 'kunyah yang berbunyi' berubah menjadi gareppu dengan perubahan bunyi vokal /a/ menjadi /e/; garra 'bentak' berubah menjadi gerra dengan perubahan bunyi vokal/a/ menjadi /e/; ipenassai 'diperjelas' berubah menjadi ipanessai dengan perubahan bunyi vokal /e/ menjadi /a/; monri 'belakang' berubah menjadi munri dengan perubahan bunyi vokal /o/ menjadi /u/; karabbe 'cakar' berubah menjadi karebbe dengan perubahan bunyi vokal /a/ menjadi /e/; kammu 'lembab’ berubah menjadi kemmu dengan perubahan bunyi vokal /a/ menjad /e/; karra 'menangis' berubah menjadi kerra dengan perubahan bunyi vokal /a/ menjadi /e/; tollua 'muntah' berubah menjadi tallua dengan perubahan bunyi vokal /o/ menjadi /a/; luppi 'lipat' berubah menjadi leppi dengan perubahan bunyi vokal /u/ menjadi /e/; dan lombu 'lumpur' berubah menjadi labbu dengan perubahan bunyi vokal /o/ menjadi $/ \mathrm{a} / \mathrm{.}$

Kata lappu 'mati atau meninggal' berubah menjadi leppu dengan perubahan bunyi vokal /a/ menjadi /e/; limba 'menyebrang' berubah menjadi lemba dengan perubahan bunyi vokal /i/ menjadi /e/; latte 'pindah' berubah menjadi lette dengan perubahan bunyi vokal /a/ menjad /e/; lasso 'lewat batas' berubah menjadi losso dengan perubahan bunyi vokal /a/ menjadi /o/; lenggu 'goyang' atau 'goyah' (perahu di dasar air)' berubah menjadi lingge dengan perubahan bunyi vokal /e/ menjadi /i/ dan /u/ menjadi /e/; 'retak' berubah malesse dengan perubahan bunyi vokal /a/ menjadi /e/, malassa 'bicara 
angkuh' berubah menjadi matompo dengan perubahan bunyi vokal /a/ menjadi /o/; molingka 'melangkah' berubah menjadi melingka dengan perubahan bunyi vokal /o/ menjadi /e/; mobanni 'bermalam' berubah menjadi mabenni dengan perubahan bunyi vokal /o/ menjadi /a/; mokareso 'kerja keras' berubah menjadi makareso dengan perubahan bunyi vokal /o/ menjadi /a/; moggoa 'menggonggong' berubah menjadi moggau dengan perubahan bunyi vokal /o/ menjadi /a/, masagga 'disegani' berubah masegge dengan perubahan bunyi vokal /a/ menjadi /e/; inannai 'dimarahi' berubah menjadi inennai dengan perubahan bunyi vokal /a/ menjadi /e/; parra 'peras' berubah menjadi perra dengan perubahan bunyi vokal /a/ menjadi /e/; pija 'lengket' berubah menjadi pije dengan perubahan bunyi vokal /a/ menjadi /e/; palenna 'letakkan' berubah menjadi palenne dengan perubahan bunyi vokal/a/ menjadi /e/; dan sulu 'obor' berubah menjadi sulo dengan perubahan bunyi vokal/u/menjadi /o/.

\section{2) Penggantian konsonan}

Penggantian konsonan dalam data inovasi fonetis tidak jauh berbeda dengan bentuk penggantian vokal inovasi fonetis sebelumnya, yaitu berubahnya bunyi konsonan kata dasar ke bunyi konsonan lain yang menghasilkan bunyi baru. Hal ini terjadi karena banyaknya bahasa berkerabat yang digunakan oleh masyarakat sekitar Kecamatan Wotu. Penelitian ini menemukan 9 glos yang mengalami penggantian konsonan, yang terdiri atas konsonan /b/, /c/, /d/, /g/, /j/, /k/, /l/, /m/, /r/ dan /s/. Berikut ini adalah data yang mengalami penggantian konsonan.

Tabel 2. Data Penggantian Konsonan Bahasa Wotu

\begin{tabular}{cccc}
\hline No. & Glos & Dialek Wotu & $\begin{array}{c}\text { Penggantian Konsonan } \\
\text { Bahasa Wotu }\end{array}$ \\
\hline 1. & Heran & Bangnga & Mangnga \\
2. & Sumbing & Cibbe & Cippe \\
3. & Pergi & Jokka & Lokka \\
4. & Bengkok & Jengko & Jekko \\
5. & Lumpur & Lombu & Labbu \\
6. & Pingsan & Limpu & Lippu \\
7. & Lewat batas & Lonci & Lonso \\
8. & Kurus & Madodo & Makojo \\
9. & Segar bugar & Magariri & Magaliri \\
\hline
\end{tabular}

Sumber: Data hasil wawancara bahasa Wotu (2018)

Berdasarkan data di atas, penggantian konsonan inovasi fonetis dapat dijelaskan sesuai dengan urutan katanya, yaitu; bangnga 'heran' berubah menjadi mangnga 
Inovasi Leksikal...

dengan perubahan bunyi konsonan /b/ menjadi /m/; cibbe 'sumbing' berubah menjadi cippe dengan perubahan bunyi konsonan /b/ menjadi /p/; jokka 'pergi' berubah menjadi lokka dengan perubahan bunyi konsonan /j/ menjadi /1/; jengko 'bengkok' berubah menjadi jekko dengan perubahan bunyi konsonan /g/ menjadi /k/; lombu lumpur' berubah menjadi labbu dengan perubahan bunyi konsonan $/ \mathrm{m} / \operatorname{menjadi} / \mathrm{b} /$; limpu 'pingsan' berubah menjadi lippu dengan perubahan bunyi konsonan /m/ menjadi /p/; lonci 'lewat batas' berubah menjadi lonso dengan perubahan bunyi konsonan /c/ menjadi /s/; madodo 'kurus' berubah menjadi makojo dengan perubahan bunyi konsonan /d/ menjadi /j/; magariri 'segar-bugar' berubah menjadi magaliri dengan perubahan bunyi konsonan/r/ menjadi /l/.

3) Penggantian silabel /ng/, /uk/, /au/, /ai/, /up/, /un/, dan /ak/ ke fonem /k/, /o/, /e/, dan /nya/.

Penggantian silabel dalam inovasi fonetis mengacu pada berubahnya bunyi sebuah silabel pada kata dasar ke bunyi silabel yang berbeda dari kata dasarnya sehingga menghasilkan bunyi baru atau kata baru, baik berupa penambahan bunyi maupun pengurangan bunyi. Kemungkinan hal ini terjadi diakibatkan banyaknya bahasa serumpun yang digunakan oleh masyarakat sekitar Kecamatan Wotu, sehingga dalam penggunaannya agak memiliki kemiripan bunyi yang saling berpengaruh antara bunyi bahasa yang satu dan bunyi bahasa yang lain. Dalam penelitian ini, ditemukan sebanyak 8 glos mengalami penggantian silabel yang terdiri atas bunyi silabel /ng/, /uk/, /au/, /ai/, /up/, /un/, dan /ak/ ke fonem /k/, /o/, /e/, dan /nya/. Berikut ini adalah data penggantian silabel pada inovasi fonetis.

Tabel 3. Data Penggantian Silabel Bahasa Wotu

\begin{tabular}{cccc}
\hline No. & Glos & Dialek Wotu & Penggantian Silabel Bahasa Wotu \\
\hline 1. & Bengkok & Jengko & Jekko \\
2. & Mangkuk & Mangkuk & Mangko \\
3. & Pisau & Pisau & Piso \\
4. & Lantai & Lantai & Lante \\
5. & Sirop & Sirup & Siro \\
6. & Karton & Karton & Karto \\
7. & Rantai & Rantai & Rante \\
8. & Minyak & Minyak & Minynya \\
\hline & & Sumber: Data hasil wawancara bahasa Wotu (2018)
\end{tabular}




\section{Inovasi Makna}

Inovasi makna dalam penelitian ini mengacu pada kesamaan pengucapan pada dua buah kata yang memiliki makna berbeda. Dalam penelitian ini ditemukan sebanyak 6 glos termasuk dalam inovasi makna. Berikut ini adalah data yang mengalami inovasi makna.

Tabel 4. Data Inovasi Makna Bahasa Wotu

\begin{tabular}{ccc}
\hline No. & Dialek Wotu & Inovasi Makna Bahasa Wotu \\
\hline 1. & Cimpi & Cungkil \\
& & Buku \\
2. & Bo & Bom \\
& & Salon (tempat cukur rambut) \\
3. & Salo & Salon (pengeras suara) \\
& Rante & Tantai \\
4. & & Kalung \\
& Kaca & Cermin \\
5. & & Gelas \\
& Gonci & Kunci \\
& & Gunting \\
\hline
\end{tabular}

Sumber: Data hasil wawancara bahasa Wotu (2018)

Berdasarkan data tersebut, inovasi makna dapat dijelaskan sesuai dengan urutan katanya, yaitu; kata 'cimpi' dengan dua makna yang berbeda, yaitu; sumbing dan cungkil; bo dengan dua makna yang berbeda, yaitu; buku dan bom; salo dengan dua makna yang berbeda, yaitu; salon (tempat pangkas rambut) dan salon (pengeras suara); rante dengan dua makna yang berbeda, yaitu; rantai dan kalung; kaca dengan dua makna yang berbeda, yaitu; cermin dan gelas; serta gonci dengan dua makna yang berbeda, yaitu; kunci dan gunting.

\section{Inovasi Morfologi}

\section{a. Prefiks Rangkap /Ipaka/}

Prefiks atau awalan, yang dimaksud dalam penelitian ini adalah perbedaan beberapa awalan, tetapi memiliki makna yang sama apabila diucapkan pada satu suku kata. Prefiks rangkap paka dapat disamakan dengan prefiks ipe-, lapa-, dan ipabergantung pada konteks kata yang akan diucapkan. Dalam penelitian ini ditemukan satu glos, yaitu sebagai berikut. 
Tabel 5. Data Prefiks Bahasa Wotu

\begin{tabular}{lccc}
\hline No & Glos & Dialek Wotu & Prefiks Bahasa Wotu \\
\hline 1. & Dipermalukan & Siri & Ipakasiri \\
\hline
\end{tabular}

Sumber: Data hasil wawancara bahasa Wotu (2018)

kata dipermalukan dalam pengucapan dialek Wotu adalah siri, ipasiri, atau ipasirki yang mengalami perubahan pengucapan menjadi ipakasiri. Prefiks ipamengalami penambahan bunyi silabel /ka/ menjadi /ipaka/ atau sama artinya dengan prefiks di-per- dalam bahasa Indonesia.

\section{b. Reduplikasi}

Reduplikasi atau kata yang berulang, baik secara utuh atau tidak utuh, dalam penelitian ini ditemukan sebanyak 4 glos. Berikut ini adalah daftar katanya.

Tabel 6. Data Reduplikasi Bahasa Wotu

\begin{tabular}{lcc}
\hline No & Glos & Reduplikasi \\
\hline 1. & Boneka & Dato-dato \\
2. & Antena & Losu-losu \\
3. & Hangat & Mapane-pane \\
4. & Anting & Anti-anti \\
\hline & Sumber: Data hasil wawancara bahasa Wotu (2018)
\end{tabular}

Data inovasi morfologi atau reduplikasi tersebut dapat dijelaskan sebagai berikut. Jika diucapkan dalam dialek Wotu, kata boneka mengalami proses reduplikasi menjadi dato-dato; kata antena mengalami proses reduplikasi menjadi losu-losu; kata hangatmengalami proses reduplikasi menjadi mapane-pane; dan kata anting mengalami proses reduplikasi menjadi anti-anti.

\section{c. Afiks}

Afiks atau akhiran yang di maksud dalam penelitian ini adalah penambahan akhiran pada sebuah suku kata untuk melengkapi maksud dan tujuan kata tersebut. Dalam penelitian ini ditemukan sebanyak 3 glos mengalami fenomena afiksasi, yaitu; afiks -nga sama dengan -ngi, - $a$, dan -ngnga. Berikut ini adalah data yang mengalami afiksasi.

Tabel 7. Data Afiksasi Bahasa Wotu

\begin{tabular}{lcc}
\hline No. & Glos & Afiksasi Bahasa Wotu \\
\hline 1. & Tumpahkan & Bolonga \\
2. & Harapan & Rannua \\
3. & Perbatasan & Pallawangnga \\
\hline
\end{tabular}

Sumber: Data hasil wawancara bahasa Wotu (2018) 
Data inovasi morfologi atau afiksasi tersebut dapat dijelaskan sebagai berikut, yaitu; kata tumpahkan dari kata dasar tumpah dalam dialek Wotu bolonga dengan kata dasar bolo mengalami fenomena afiksasi dalam bahasa Indonesia berafiks -kan dan dalam dialek Wotu berafiks -nga sehingga menjadi bolo-nga; harapan dari kata dasar harap dalam dialek Wotu rannua dengan kata dasar rannu mengalami fenomena afiksasi dalam bahasa Indonesia berafiks -an dan dalam dialek Wotu berafiks - $a$ sehingga menjadi rannua; serta kata perbatasan dari kata dasar batas dalam dialek Wotu pallawangnga dengan kata dasar lawa mengalami fenomena afiksasi dalam bahasa Indonesia berafiks - an dan dalam dialek Wotu berafiks -ngnga sehingga menjadi pallawangnga.

\section{Inovasi Leksikal}

Dalam penelitian ini inovasi leksikal atau pembaruan yang mengkaji makna kata alah beberapa suku kata yang berbeda, tetapi memiliki makna yang sama. Penelitian ini menemukan sebanyak 7 glos mengalami inovasi leksikal. Berikut ini adalah data yang mengalami inovasi leksikal.

Tabel 8. Data Inovasi Leksikal Bahasa Wotu

\begin{tabular}{lcc}
\hline No & Glos & Inovasi Leksikal Bahasa Wotu \\
\hline 1. & Sumbing & Cippe \\
& & Cimpi \\
2. & Cungkil & Cukke \\
& & Sukke \\
3. & Selek & Dake \\
& & Kadake \\
& & Karekke \\
4. & Madda \\
& & Kapoda \\
5. & Mapoda \\
& & Mampoddo \\
& & Lajo \\
6. & Benjulang tinggi & Lonjo \\
& & Loli \\
& & Molauli \\
7. & Mengeles & Musonsourio \\
& & Mburemonsou \\
& & Masaleo \\
& & Mawewe \\
& & Kacele \\
\hline
\end{tabular}

Sumber: Data hasil wawancara bahasa Wotu (2018)

Inovasi leksikal dapat dijelaskan berdasarkan urutan katanya, yaitu; kata sumbing mengalami fenomena inovasi leksikal atau kesamaan makna daengan kata 
Inovasi Leksikal...

cibbe, cippe, dan cimpi; cungkil mengalami fenomena inovasi leksikal atau kesamaan makna daengan kata cukke, sukke, dan sibbe; jelek mengalami fenomena inovasi leksikal atau kesamaan makna dengan kata dake, kadake, karekke, dan madda, pendek (sejenis pakaian) mengalami fenomena inovasi leksikal atau kesamaan makna daengan kata kapoda, mapoda, dan mampoddo, menjulang tinggi mengalami fenomena inovasi leksikal atau kesamaan makna daengan kata lajo, lonjo, dan loli; bolak-balik mengalami fenomena inovasi leksikal atau kesamaan makna dengan kata molauli, musonsourio, dan mburemonso; mengeles mengalami fenomena inovasi leksikal atau kesamaan makna dengan kata masaleo, mawewe, dan kacele.

Selain inovasi dalam bentuk fonetis, makna, morfologi, dan leksikal, terdapat pula inovasi dalam bentuk lain, seperti inovasi leksikal penuh dan inovasi leksikal persial. Hal ini dipicu munculnya kata-kata baru pada era perkembangan zaman sekarang.

\section{a. Inovasi Leksikal Parsial}

Hal ini terjadi karena munculnya berbagai macam kosakata baru pada era modern yang mengakibatkan terciptanya dialek baru dan memiliki kemiripan fonem atau bunyi di berbagai tataran bahasa daerah, salah satunya di wilayah Kecamatan Wotu. Fenomena ini terjadi karena serapan bahasa Indonesia atau Melayu. Dalam penelitian ini peneliti menemukan sebanyak 39 glos yang mengalami inovasi parsial.

Berdasarkan data inovasi parsial yang ditemukan dapat dideskripsikan leksem yang mengalami inovasi parsial. Kata pusar mengalami fenomena inovasi persial dari bahasa Melayu ke bahasa Wotu menjadi puse; pulpen mengalami fenomena inovasi persial dari bahasa Melayu menjadi polope; mangkok mengalami fenomena inovasi persial dari bahasa Melayu ke bahasa Wotu menjadi mangko; jaket mengalami fenomena inovasi persial dari bahasa Melayu ke bahasa Wotu menjadi jase; kalender mengalami fenomena inovasi persial dari bahasa Melayu ke bahasa Wotu menjadi kalendere; kapur mengalami fenomena inovasi persial dari bahasa Melayu ke bahasa Wotu menjadi kapuru; sepeda mengalami fenomena inovasi persial dari bahasa Melayu ke bahasa Wotu menjadi sapeda; listrik mengalami fenomena inovasi persial dari bahasa Melayu ke bahasa Wotu menjadi litri; lemari mengalami fenomena inovasi persial dari bahasa Melayu ke bahasa Wotu menjadi lamari; salon (tempat pangkas rambut) mengalami fenomena inovasi persial dari bahasa Melayu ke bahasa Wotu 
menjadi salo; salon (pengeras suara)" mengalami fenomena inovasi persial dari bahasa Melayu ke bahasa Wotu menjadi salo; plastik mengalami fenomena inovasi persial dari bahasa Melayu ke bahasa Wotu menjadi palasti.

Kata keranjang mengalami fenomena inovasi persial dari bahasa Melayu ke bahasa Wotu menjadi karanja; helm mengalami fenomena inovasi persial dari bahasa Melayu ke bahasa Wotu menjadi helle; tas mengalami fenomena inovasi persial dari bahasa Melayu ke bahasa Wotu menjadi tase; tang mengalami fenomena inovasi persial dari bahasa Melayu ke bahasa Wotu menjadi ta; semen mengalami fenomena inovasi persial dari bahasa Melayu ke bahasa Wotu menjadi semme; wakil mengalami fenomena inovasi persial dari bahasa Melayu ke bahasa Wotu menjadi wakkele; senter mengalami fenomena inovasi persial dari bahasa Melayu ke bahasa Wotu menjadi sentere; kartun mengalami fenomena inovasi persial dari bahasa Melayu ke bahasa Wotu menjadi karto; spidol mengalami fenomena inovasi persial dari bahasa Melayu ke bahasa Wotu menjadi sipidol; sekolah mengalami fenomena inovasi persial dari bahasa Melayu bahasa Wotu menjadi sikolah; bengsin mengalami fenomena inovasi persial dari bahasa Melayu ke bahasa Wotu menjadi bengsi; minyak mengalami fenomena inovasi persial dari bahasa Melayu ke bahasa Wotu menjadi minynya; cat mengalami fenomena inovasi persial dari bahasa Melayu ke bahasa Wotu menjadi ce; motor mengalami fenomena inovasi persial dari bahasa Melayu ke bahasa Wotu menjadi motoro; becak mengalami fenomena inovasi persial dari bahasa Melayu ke bahasa Wotu menjadi beca; leluasa mengalami fenomena inovasi persial dari bahasa Melayu ke bahasa Wotu menjadi laluasa; serta sirop mengalami fenomena inovasi persial dari bahasa Melayu ke bahasa Wotu menjadi siro.

\section{b. Inovasi Leksikal Penuh}

Inovasi leksikal penuh maksudnya adalah, pembaruan yang dianggap benar-benar baru atau tidak memiliki kesamaan dalam segi fonetiknya. Dalam penelitian ini peneliti menemukan sebanyak 23 glos yang mengalami inovasi leksikal penuh. Berikut ini adalah data yang mengalami inovasi leksikal penuh.

Kata kamera mengalami inovasi leksikal penuh dari bahasa Melayu ke bahasa Wotu menjadi potere; pensil mengalami inovasi leksikal penuh dari bahasa Melayu ke bahasa Wotu menjadi potolo; tirai mengalami inovasi leksikal penuh dari bahasa 
Inovasi Leksikal...

Melayu ke bahasa Wotu menjadi pallawalallawwe; kertas mengalami inovasi leksikal penuh dari bahasa Melayu ke bahasa Wotu menjadi bua; karet mengalami inovasi leksikal penuh dari bahasa Melayu ke bahasa Wotu menjadi gatta; kaleng mengalami inovasi leksikal penuh dari bahasa Melayu ke bahasa Wotu menjadi belle; lap mengalami inovasi leksikal penuh dari bahasa Melayu ke bahasa Wotu menjadi palullu; sари mengalami inovasi leksikal penuh dari bahasa Melayu ke bahasa Wotu menjadi pasaringi; kelas mengalami inovasi leksikal penuh dari bahasa Melayu ke bahasa Wotu menjadi bili; operasi (bedah) mengalami inovasi leksikal penuh dari bahasa Melayu ke bahasa Wotu menjadi jenje; sampiran mengalami inovasi leksikal penuh dari bahasa Melayu ke bahasa Wotu menjadi potakkaie; toples mengalami inovasi leksikal penuh dari bahasa Melayu ke bahasa Wotu menjadi palese.

Kata mainan mengalami inovasi leksikal penuh dari bahasa Melayu ke bahasa Wotu menjadi pamboressa; penghapus mengalami inovasi leksikal penuh dari bahasa Melayu ke bahasa Wotu menjadi paledda; takraw mengalami inovasi leksikal penuh dari bahasa Melayu ke bahasa Wotu menjadi raga; ejek mengalami inovasi leksikal penuh dari bahasa Melayu ke bahasa Wotu menjadi gente; bentak mengalami inovasi leksikal penuh dari bahasa Melayu ke bahasa Wotu menjadi garra; tidak masuk akal atau tidak logis mengalami inovasi leksikal penuh dari bahasa Melayu ke bahasa Wotu menjadi garamba; keras kepala mengalami inovasi leksikal penuh dari bahasa Melayu ke bahasa Wotu menjadi bantullu; merusak mengalami inovasi leksikal penuh dari bahasa Melayu ke bahasa Wotu menjadi makkasolla; belajar mengalami inovasi leksikal penuh dari bahasa Melayu ke bahasa Wotu menjadi mingguru; menulis mengalami inovasi leksikal penuh dari bahasa Melayu ke bahasa Wotu menjadi moruki; gulung mengalami inovasi leksikal penuh dari bahasa Melayu ke bahasa Wotu menjadi bunta.

Inovasi atau pembaruan, baik dari segi makna maupun bentuk katanya, adalah salah satu fenomena kebahasaan yang perlu diperhatikan, khususnya di Kecamatan Wotu yang memiliki keberagaman suku sehingga besar kemungkinan terjadinya percampuran dialek yang satu dengan dialek yang lain.

Sejalan dengan analisis deskriptif kualitatif, penelitian ini menunjukkan bahwa, inovasi leksikal bahasa Wotu di Kecamatan Wotu, Kabupaten Luwu Timur atau fenomena kebahasaan mengenai pembaruan bahasa Wotu benar-benar terjadi. 
Fenomena ini dapat dilihat pada pemunculan 152 glos dan 191 bentuk kata inovasi, yang terdiri atas inovasi fonetis, inovasi makna, inovasi morfologi, dan inovasi leksikal.

Sejalan dengan uraian tersebut, setelah dilakukuan pengolahan data, ditemukan beberapa bentuk fenomena kebahasaan dari keempat inovasi itu, yaitu pada inovasi fonetis mucul pembaruan dengan bentuk penggantian vokal dan konsonan, penambahan bunyi vokal dan konsonan, dan penghilangan bunyi vokal dan konsonan serta gugus konsonan pada posisi kanan. Inovasi makna membahas tentang pembaruan dari segi makna katanya atau kesamaan bentuk kata dasar yang memiliki makna berbeda. Inovasi morfologis terdiri atas prefiks, sufiks, afiks, dan reduplikasi. Inovasi leksikal membahas tentang perbedaan bentuk kata untuk makna yang sama. Selain itu, ditemukan pula inovasi leksikal parsial atau pembaruan akibat serapan bahasa Melayu dan inovasi leksikal penuh atau pembaruan yang dianggap benar-benar baru.

Selain memiliki fenomena kebahasaan, bahasa Wotu juga merupakan alat komunikasi yang tergolong terancam punah. Hal ini terlihat dari peralihan dan pergeseran dialeknya, karena penutur bahasa Wotu hanya tersisa beberapa orang saja, itu pun mereka ujarkan pada tempat-tempat tertentu.

\section{PENUTUP}

Berdasarkan hasil analisis glos yang ditemukan, dapat disimpulkan bahwa inovasi leksikal bahasa Wotu meliputi inovasi fonetis, inovasi makna, inovasi morfologi, dan inovasi leksikal. Pada inovasi fonetis peneliti menemukan bentuk yang terdiri atas penggantian vokal sebanyak 31 kata, penggantian konsonan sebanyak 9 kata, penggantian silabel /ng/, /uk/, /au/, /ai/, /up/, /un/, dan /ak/ ke fonem /k/, /o/, /e/, dan /nya/ sebanyak 8 kata, penambahan vokal sebanyak 10 kata, penambahan konsonan sebanyak 3 kata, penghilangan vokal sebanyak 1 kata, penghilangan konsonan sebanyak 16 kata, (2 di awal kata, 2 di pertengahan kata dan 12 di akhir kata), gugus konsonan posisi kanan sebanyak 30 kata, inovasi makna sebanyak 6 kata, inovasi morfologi yang meliputi prefiks rangkap ipaka- sebanyak 1 kata, reduplikasi sebanyak 4 kata, afiks sebanyak 3 kata, dan inovasi leksikal sebanyak 24 kata. Selain itu, ditemukan pula inovasi dalam bentuk parsial atau inovasi leksikal parsial sebanyak 39 kata dan inovasi leksikal penuh sebanyak 23 kata. 
Inovasi Leksikal...

\section{DAFTAR PUSTAKA}

Adhiti, I A I. (2016). Pengelompokan Genetis Bahasa Kabola, Bahasa Hampa, dan Bahasa Klon di Pulau Alor Nusa Tenggara Timur. Jurnal Tutur, Volume 2 Nomor 1 (hlm. 51).

Cahyono. (1995). Kristal-Kristal Ilmu Bahasa. Surabaya: Airlangga University.

Chaer, A. dan Agustina, L. (2010). Sosiolinguistik. Jakarta: Rineka Cipta.

Junaidi, Y. J. dan Rismayeti. (2016). Variasi Inovasi Leksikal Bahasa Melayu Riau di Kecamatan Merbau. Jurnal Pustaka Budaya, Volume 3 Nomor 1. https://journal.unilak.ac.id/index.php/pb/article/view/582

Junawaroh, S. dan Hidayat, A. (2013). Leksikon Bahasa Jawa dalam Bahasa Sunda di Kabupaten Brebes. Jurnal Bahasa dan Sastra. Volume 12 Nomor 1.

Kridalaksana, Harimurti. (1993). Fungsi Bahasa dan Sikap Bahasa. Edisi Kedua. Cetakan Pertama. Ende: Nusa Indah.

Kurniawati, D. (2017). Inovasi Leksikal Bahasa Jawa di Kabupaten Pringsewu Lampung. Jurnal Pesona. Volume 3 Nomor 1 (hlm. 52-52).

Mulatsih, Devi. (2016). Inovasi Bentuk dalam Bahasa Sunda di Kampung Puyuh Koneng, Desa Kencana Harapan, Kecamatan Lebak Wangi, Kabupaten Serang, Provinsi Banten. Jurnal Logika, Vol. XVII, No. 2.

Mustafa, M. N., Faizah, H., dan Yani, J. (2015). Kajian Dialek Geografi pada Inovasi Leksikal Penuh Bahasa Melayu Riau Dialek Kampar di Kecamatan Kampar Timur. Proceding: $7^{\text {th }}$ International Seminar on Regional Education November 5-7 Volume 1 (hlm. 594).

Pei, Mario. (1996). Glossary of Linguistic Terminology. New York and London: Columbia University Press.

Sudika I. Nyoman. (2010). Inovasi Leksikal Bahasa Bali di Lombok: Kajian Dialektologi. Mabasan, Vol. 4 No. 1 Januari-Juni 2010. DOI: https://doi.org/10.26499/mab.v4i1.185

Suriono, D. A. (2016). Pengantar Dialektologi. Yogyakarta: CAPS (Center For Academic Publishing Service).

Syahrir, E. (2018). Variasi Leksikal Tiga Isolek dalam Keluarga Bahasa Melayu Riau. Jurnal Madah Volume 8, Nomor 2 (hlm. 196). DOI: http://dx.doi.org/10.31503/madah.v8i2.635

Toha, Muhammad. 2016. Retensi dan Inovasi Fonologis Protobahasa Melayik pada Bahasa Melayu Tamiang. Jurnal Ranah Volume 5, Nomor 1 Juni 2016 (hlm. 88). DOI: https://doi.org/10.26499/rnh.v5i1.40

Wahya. (2006). Inovasi dan Defnisi Leksikal Bahasa Melayu dan Bahasa Sunda di Perbatasan Bogor-Bekasi: Kajian Geolinguistik. Bandung: Desertasi. Universitas Padjadjaran (hlm. $52)$. 